\title{
Yield of Cowpea Genotypes Inoculated With Bradyrhizobium and Azospirillum brasilense in Association With Phosphate Fertilization in Amazonian Soil
}

\author{
E. O. Araújo ${ }^{1}$, M. $\mathrm{Mauad}^{2}$, H. C. Tadeu ${ }^{3} \&$ H. A. Lima Filho ${ }^{4}$ \\ ${ }^{1}$ Federal Institute of Education, Science and Technology, Rodonia State, Campus Cacoal, Brazil \\ ${ }^{2}$ Faculty of Agricultural Sciences, Federal University of Grande Dourados, Dourados, Brazil \\ ${ }^{3}$ Federal University of Amazonas, Manaus, Brazil \\ ${ }^{4}$ Federal Institute of Education, Science and Technology Goiano, Brazil \\ Correspondence: E. O. Araújo, Federal Institute of Education, Science and Technology Rodonia State, Cacoal, \\ Brazil. E-mail: erica.araujo@ifro.edu.br
}

Received: August 17, 2018

doi:10.5539/jas.v10n12p306
Accepted: September 25, 2018

Online Published: November 15, 2018

URL: https://doi.org/10.5539/jas.v10n12p306

\begin{abstract}
The use of inoculants containing $\mathrm{N}_{2}$-fixing bacteria increases every year in cowpea crop in the North and Northeast regions of Brazil. In this context, this study aimed to evaluate the effects of inoculation with Bradyrhizobium sp. and Azospirillum brasilense in association with phosphate fertilization on the vegetative development, nodulation and yield of cowpea genotypes grown in Southern Rondônia state, Brazil. The experiment was conducted from February to May 2018, in the municipality of Colorado do Oeste, RO. The experimental design was randomized blocks in $4 \times 3 \times 2$ factorial scheme, corresponding to four dose of phosphorus $\left(0,80,120\right.$ and $160 \mathrm{~kg} \mathrm{ha}^{-1}$ of $\left.\mathrm{P}_{2} \mathrm{O}_{5}\right)$; absence, inoculation and co-inoculation with rhizobacteria; two cowpea genotypes (White and Butter), with three replicates. Cowpea seeds were inoculated with the commercial inoculant TotalNitro Cowpea with strains of Bradyrhizobium sp. (Semia 6462 and Semia 6463); co-inoculation was performed using the commercial product, containing a combination of strains of Azospirillum brasilense, both in liquid formulation. Co-inoculation (Bradyrhizobium sp.+ Azospirillum brasilense) did not influence the production components of cowpea plants. Inoculation with Bradyrhizobium $s p$. associated with phosphate fertilization of $120 \mathrm{~kg} \mathrm{ha}^{-1}$ of $\mathrm{P}_{2} \mathrm{O}_{5}$ was sufficient to promote maximum growth and development of cowpea plants in Amazonian soil. The genotype White had higher capacity of nodulation, dry matter production and grain yield. Inoculation of Bradyrhizobium $s p$. increased $\mathrm{N}$ and $\mathrm{P}$ contents in the leaves. The genotype Butter was superior to the genotype White with respect to the accumulation of $\mathrm{P}, \mathrm{K}, \mathrm{Ca}$ and $\mathrm{Mg}$ in the leaves.
\end{abstract}

Keywords: Vigna unguiculata, phosphorus, rhizobacteria, symbiosis

\section{Introduction}

With origin in Africa, the cowpea crop (Vigna unguiculata (L.) Walp.) is extremely rustic, tolerant to high temperatures and drought, and with good conditions for adaptation and expansion of exploited areas. In Brazil, it is estimated that 1.442 million hectares of cowpea are cultivated, with mean yield of approximately $496 \mathrm{~kg} \mathrm{ha}^{-1}$ (CONAB, 2018), which allows the crop to appear among the main leguminous species cultivated in the country, with predominance in the North and Northeast regions (CONAB, 2018). In addition, in some regions of the country this crop has become an important option for cultivation in the second season, in succession to traditional crops, such as corn and soybean, especially due to the low cost of production and adaptation to the rainfall regime (Zilli et al., 2011).

The utilization of biological inputs in replacement of industrialized chemical inputs has been increasingly frequent in agriculture, and biological nitrogen fixation (BNF) has proved to be indispensable for the sustainability of the Brazilian agriculture (Hungria et al., 2007), being considered as an important strategy to increase cowpea yield (Melo \& Zilli, 2009). In the Amazonian region, studies have shown positive results for the increase in grain yield with inoculation of bacteria of the genus Bradyrhizobium in cowpea seeds (Araujo et al., 
2018; Araujo et al., 2017; Rocha, 2016; Melo \& Zilli, 2009), reducing production costs and increasing the producer's income.

Cowpea can produce nodules and establish symbiosis with several species of bacteria, such as the genus Azospirillum sp. Such low specificity of the crop regarding the microsymbiont proves to be limiting to the technological exploitation of BNF, since nodulating bacteria established in the soil, besides being competitive and in high number, exhibit variable efficiency in BNF (Hara \& Oliveira, 2007). In addition to these peculiarities inherent to the microsymbiont, there are also reports that certain cowpea genotypes have higher capacity for nodulation and efficiency in BNF.

However, the benefits of the ecological processes performed by plant growth-promoting bacteria (PGPB) have contributed to achieving sustainability in the agricultural sector. Co-inoculation between rhizobium and PGPB can lead to increased nodulation and fixation of atmospheric $\mathrm{N}_{2}$ and also to improvements in plant growth and development. However, the efficiency of $\mathrm{N}_{2}$ fixation depends on the availability of $\mathrm{P}$, due to its participation in the symbiotic process (Burity et al., 2000). Several studies have already observed the effect of phosphate fertilization on the growth and nodulation of cowpea plants (Araujo et al., 2018; Araujo et al., 2017; Coutinho et al., 2014; Araujo et al., 2012; Silva et al., 2010a; Silva et al., 2010b), but information on the response of different genotypes is scarce in the literature. Thus, further research is necessary, for each species, especially with respect to the peculiarities related to growth promotion by Azospirillum brasilense combined with Bradyrhizobium sp., since alterations in biometric and production components can be an indication of the effect of the association between diazotrophic bacteria.

Given the above, the present study aimed to evaluate the effects of inoculation with Bradyrhizobium sp. and Azospirillum brasilense in association with phosphate fertilization on the vegetative development, nodulation and yield of cowpea genotypes grown in southern Rondônia state, Brazil.

\section{Materials and Methods}

The experiment was carried out from February to May 2018 in the experimental area of the Federal Institute of Education, Science and Technology of Rondônia, municipality of Colorado do Oeste, RO, Brazil, at geographic coordinates $13^{\circ} 06^{\prime} 23.51^{\prime \prime} \mathrm{S}$ and $60^{\circ} 30^{\prime} 37.65^{\prime \prime} \mathrm{W}, 412 \mathrm{~m}$, in Red Yellow Latosol. The climate according to Köppen's classification is Awa, hot and humid tropical with two well-defined seasons. Mean data of temperature and rainfall along the experiment were obtained from the database of the National Institute of Meteorology (INMET).

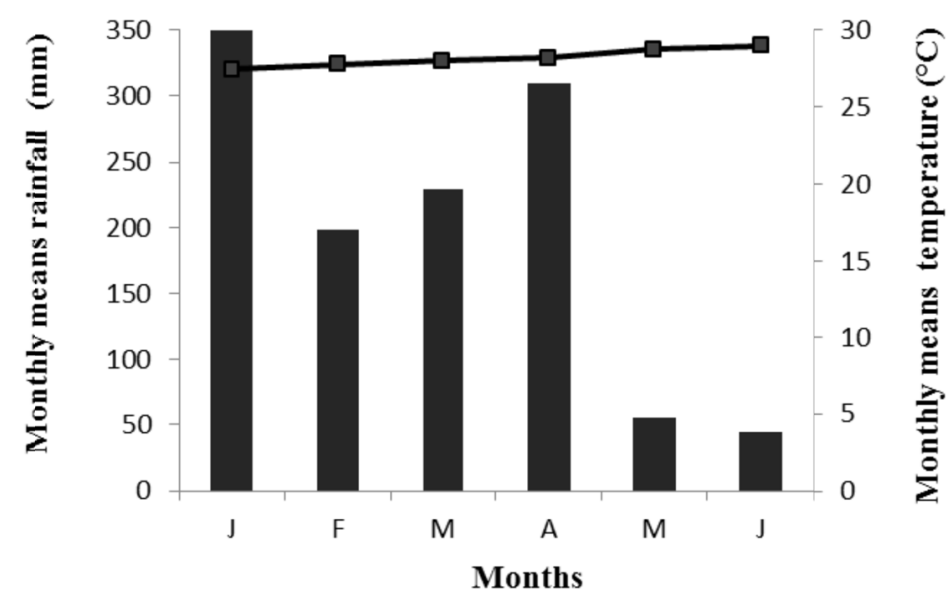

Figure 1. Mean monthly rainfall $(\mathrm{mm})$ and temperature $\left({ }^{\circ} \mathrm{C}\right)$, recorded at the meteorological station of the National Institute of Meteorology from February to May in the agricultural year of 2018

The chemical analysis of the soil sample collected in the $0-20 \mathrm{~cm}$ layer, carried out before the experiment, showed the following chemical and granulometric characteristics: O.M.: $35.8 \mathrm{~g} \mathrm{dm}^{-3} ; \mathrm{pH}\left(\mathrm{CaCl}_{2}\right): 5.1 ; \mathrm{P}: 1 \mathrm{mg}$ $\mathrm{dm}^{-3}$; K: 2 mmolc dm${ }^{-3}$; Ca: 94 mmolc dm${ }^{-3} ; \mathrm{Mg}: 13$ mmolc dm${ }^{-3} ; \mathrm{Al}: 1$ mmolc dm${ }^{-3} ; \mathrm{H}+\mathrm{Al}: 29 \mathrm{mmolc} \mathrm{dm}^{-3}$; SB: $109 \mathrm{mmolc} \mathrm{dm}^{-3}$; CEC: $138 \mathrm{mmolc} \mathrm{dm}$, base saturation: $79 \%, 576 \mathrm{~g} \mathrm{dm}^{-3}$ of clay, $178 \mathrm{~g} \mathrm{dm}^{-3}$ of sand $246 \mathrm{~g} \mathrm{dm}^{-3}$ of silt. 
The experimental design was randomized blocks in a $4 \times 3 \times 2$ factorial scheme, corresponding to four doses of phosphorus; absence, inoculation and co-inoculation with rhizobacteria; and two local cowpea genotypes (White and Butter), with three replicates. The P doses were 0, 80, 120 and $160 \mathrm{~kg} \mathrm{ha}^{-1}$ of $\mathrm{P}_{2} \mathrm{O}_{5}$, applied in the planting furrow. The source of $\mathrm{P}_{2} \mathrm{O}_{5}$ used was single superphosphate $\left(21 \% \mathrm{P}_{2} \mathrm{O}_{5}\right)$. The cowpea genotypes used exhibit highly upright habit, indeterminate growth and do not tend to entwine on the stake.

Basal fertilization consisted of nitrogen and potassium, using $30 \mathrm{~kg} \mathrm{ha}^{-1}$ of $\mathrm{N}$ and $60 \mathrm{~kg} \mathrm{ha}^{-1}$ of $\mathrm{K}_{2} \mathrm{O}$, in the form of urea $(45 \% \mathrm{~N})$ and potassium chloride $\left(56 \% \mathrm{~K}_{2} \mathrm{O}\right)$, respectively, incorporated to the soil.

Cowpea seeds were inoculated with the commercial inoculant TotalNitro cowpea (concentration of $2 \times 10^{9}$ $\mathrm{CFU} / \mathrm{mL}$ ) with strains of Bradyrhizobium sp. (Semia 6462 and Semia 6463). The rate used was $100 \mathrm{~mL}$ of the liquid inoculant for $50 \mathrm{~kg}$ of seeds; for co-inoculation, a commercial product was used, containing a combination of strains of Azospirillum brasilense. The applied rate was $150 \mathrm{~mL}$ for every $50 \mathrm{~kg}$ of seeds. Both inoculants were used in liquid formulation, produced and donated by the company Total Biotecnologia.

Soil tillage included harrowing (disc harrow) to $15 \mathrm{~cm}$ depth. Planting and fertilization furrows were opened by hand using a hoe at depths between 5 and $10 \mathrm{~cm}$. Sowing was manually performed using a hand-held planter known as "matraca", by placing four seeds per hole, and five plants per linear meter were left after thinning. Each experimental unit comprised three 4-m-long rows, at spacing of $0.60 \mathrm{~m}$ between rows and $0.20 \mathrm{~m}$ between plants. The evaluated area in each plot corresponded to the central row, disregarding $0.5 \mathrm{~m}$ on each end. At 8 days after emergence (DAE), thinning was performed to leave only one plant/hole. At 10 and 30 DAE, insecticide with the active ingredients Imidacloprid $100 \mathrm{~g} / \mathrm{L}$ and Beta-cyfluthrin $12.5 \mathrm{~g} / \mathrm{L}$, of the chemical groups Neonicotinoid (Imidacloprid) and Pyrethroid (Beta-cyfluthrin), was applied at dose of $750-1000 \mathrm{~mL} / \mathrm{ha}$ to control Diabrotica speciosa. Weeds were controlled by manual weeding every 15 days.

At full flowering (50\% of plants at flowering), 20 trifoliate leaves were collected in each plot for the determination of $\mathrm{N}, \mathrm{P}, \mathrm{K}, \mathrm{Ca}, \mathrm{Mg}$ and $\mathrm{S}$ contents in the leaves. Sampling was carried out in the middle third of the plants in the evaluated area of the plots. All plant material collected was washed in running water and deionized water, and the samples were placed in paper bags, dried in forced air circulation oven at temperature of $65^{\circ} \mathrm{C}$ for $72 \mathrm{~h}$, and then ground. Ground samples were subjected to sulfuric digestion and nitric-perchloric digestion, using the methodology described in Embrapa (2009). At this same phenological stage, the following parameters were determined: plant height, measured as the distance between collar and apical meristem using a tape measure; stem diameter, measured with a digital caliper at $2 \mathrm{~cm}$ height from the collar; number of leaves per plant and number of viable nodules, obtained by counting. Number of pods per plant, number of grains per pod and number of grains per plant were determined based on the mean number of pods harvested in five plants of the evaluated area of each plot. Shoot, root and total dry matter and grain yield were determined in the period of physiological maturation of the crop, R5 phenological stage. Yield was determined by the weight of grains in the evaluated area of each plot in kilograms, with correction to $13 \%$ moisture content, transforming the data to $\mathrm{kg}$ $\mathrm{ha}^{-1}$.

The data were subjected to normality test (Shapiro-Wilk) and analysis of variance using the statistical analysis program Sisvar. The effects between inoculation and co-inoculation, for each genotype, were evaluated by Tukey test at 0.05 probability level. For variables with statistical significance as a function of the rates of $\mathrm{P}$, regression analysis was used.

\section{Results and Discussion}

The results showed significant effects $(p \leq 0.05)$ of the triple interaction between genotype $(G) \times$ dose $(D) \times$ bacterium (B) on plant height, stem diameter, number of leaves, number of nodules, number of pods per plant, number of grains per pod, number of grains per plant, shoot dry matter, root dry matter, total dry matter and yield. Conversely, N, P, K, Ca, Mg and S contents in the leaves at full flowering were not significantly affected by the interaction and were presented independently for each genotype, rate and bacterium (Table 1 and 2). 
Table 1. F values, Mean and CV for plant height (PH), stem diameter (SD), number of leaves (NL), number of nodules (NNO), shoot dry matter (SDM), root dry matter (RDM), total dry matter (TDM), number of pods per plant (NP), number of grains per pod (NG), number of grains per plant (NG/PL) and yield (Y) of cowpea genotypes inoculated and co-inoculated with rhizobacteria in association with phosphate fertilization. Colorado do Oeste, RO, Brazil (2018)

\begin{tabular}{|c|c|c|c|c|c|c|c|c|c|c|c|c|}
\hline \multirow{2}{*}{ Source of variation } & \multirow{2}{*}{ GL } & \multicolumn{11}{|c|}{$\operatorname{Pr}>F$} \\
\hline & & $\mathrm{PH}$ & $\mathrm{SD}$ & NL & $\mathrm{NNO}$ & SDM & RDM & TDM & NP & NG & NG/PL & $\mathrm{Y}$ \\
\hline Genotype (G) & 1 & $0.00 *$ & $0.00 *$ & $0.00 *$ & $0.00^{*}$ & $0.00 *$ & $0.00^{*}$ & $0.00 *$ & $0.00 *$ & 0.11 & $0.00 *$ & $0.00^{*}$ \\
\hline Dose (D) & 3 & $0.00^{*}$ & $0.00 *$ & $0.00 *$ & $0.00 *$ & $0.00 *$ & $0.00 *$ & $0.00 *$ & $0.00 *$ & $0.00^{*}$ & $0.00 *$ & $0.00 *$ \\
\hline Bacteria (B) & 2 & $0.00 *$ & $0.00 *$ & $0.00 *$ & $0.00^{*}$ & $0.00 *$ & $0.00 *$ & $0.00^{*}$ & $0.00 *$ & $0.00^{*}$ & $0.00 *$ & $0.00^{*}$ \\
\hline $\mathrm{G} \times \mathrm{D}$ & 3 & $0.00 *$ & $0.01 *$ & $0.00 *$ & $0.00 *$ & $0.00 *$ & $0.00 *$ & $0.00 *$ & $0.00 *$ & 0.37 & $0.00 *$ & 0.24 \\
\hline $\mathrm{G} \times \mathrm{B}$ & 2 & $0.00^{*}$ & $0.00 *$ & $0.00 *$ & $0.00 *$ & 0.23 & $0.01 *$ & 0.24 & $0.00 *$ & 0.03 & $0.00 *$ & $0.00^{*}$ \\
\hline $\mathrm{D} \times \mathrm{B}$ & 6 & $0.00^{*}$ & $0.00^{*}$ & $0.00 *$ & $0.00 *$ & 0.07 & $0.00 *$ & 0.15 & $0.00 *$ & $0.00^{*}$ & $0.00 *$ & $0.00^{*}$ \\
\hline $\mathrm{G} \times \mathrm{D} \times \mathrm{B}$ & 6 & $0.00 *$ & $0.04 *$ & $0.00 *$ & $0.00^{*}$ & $0.00 *$ & $0.00 *$ & $0.00 *$ & $0.00^{*}$ & $0.00^{*}$ & $0.00 *$ & $0.00^{*}$ \\
\hline Residue & 71 & & & & & & & & & & & \\
\hline Mean & & 85.20 & 12.13 & 29.75 & 109.63 & 72.54 & 15.46 & 88.00 & 14.47 & 14.73 & 233.48 & 620.25 \\
\hline CV (\%) & & 3.78 & 6.22 & 5.34 & 4.41 & 10.64 & 6.26 & 8.98 & 4.95 & 4.45 & 5.45 & 8.26 \\
\hline
\end{tabular}

Note. *: significant by Tukey test at $5 \%$ probability. CV: coefficient of variation.

Table 2. F values, Mean and CV for the contents of nitrogen $(\mathrm{N})$, phosphorus $(\mathrm{P})$, potassium $(\mathrm{K})$, calcium $(\mathrm{Ca})$, magnesium $(\mathrm{Mg})$ and sulfur $(\mathrm{S})$ in the leaves of cowpea plants at full flowering inoculated and co-inoculated with rhizobacteria in association with phosphate fertilization. Colorado do Oeste, RO, Brazil (2018)

\begin{tabular}{llllllll}
\hline \multirow{2}{*}{ Source of variation } & \multirow{2}{*}{$\mathrm{GL}$} & \multicolumn{7}{c}{$\mathrm{Pr}>\mathrm{F}$} \\
\cline { 3 - 8 } & & $\mathrm{N}$ & $\mathrm{P}$ & $\mathrm{K}$ & $\mathrm{Ca}$ & $\mathrm{Mg}$ & $\mathrm{S}$ \\
\hline Genotype (G) & 1 & 0.38 & $0.00^{*}$ & $0.00^{*}$ & $0.00^{*}$ & $0.01^{*}$ & 0.09 \\
Dose (D) & 3 & $0.00^{*}$ & $0.00^{*}$ & $0.01^{*}$ & $0.01^{*}$ & 0.07 & 0.22 \\
Bacteria (B) & 2 & $0.01^{*}$ & $0.00^{*}$ & 0.54 & 0.62 & 0.74 & $0.00^{*}$ \\
$\mathrm{G} \times \mathrm{D}$ & 3 & 0.10 & 0.21 & 0.32 & 0.05 & 0.18 & 0.73 \\
$\mathrm{G} \times \mathrm{B}$ & 2 & 0.12 & 0.20 & 0.31 & 0.58 & 0.35 & 0.25 \\
$\mathrm{D} \times \mathrm{B}$ & 6 & 0.06 & 0.15 & 0.07 & 0.06 & 0.34 & 0.06 \\
$\mathrm{G} \times \mathrm{D} \times \mathrm{B}$ & 6 & $0.06^{*}$ & 0.15 & 0.08 & 0.18 & 0.54 & 0.98 \\
Residue & 71 & & & & & \\
- Mean & & 34.78 & 2.50 & 15.61 & 41.56 & 3.58 & 2.41 \\
CV $(\%)$ & & 9.27 & 9.57 & 13.62 & 14.41 & 16.23 & 14.50 \\
\hline
\end{tabular}

Note. *: significant by Tukey test at 5\% probability. CV: coefficient of variation.

In the simple-effect analysis of the triple interaction, it was observed that the genotype White was statistically superior to Butter when co-inoculated and fertilized with $160 \mathrm{~kg} \mathrm{ha}^{-1}$ of $\mathrm{P}$. The dose of $160 \mathrm{~kg} \mathrm{ha}^{-1}$ of P in the presence of Bradyrhizobium sp. + Azospirillum brasilense led to maximum height and stem diameter, statistically differing from the treatment inoculated and fertilized with $160 \mathrm{~kg} \mathrm{ha}^{-1}$ of P and from the treatment fertilized with $160 \mathrm{~kg} \mathrm{ha}^{-1}$ of $\mathrm{P}$ and without inoculation (Table 3). In the genotype White, co-inoculated and fertilized with $160 \mathrm{~kg} \mathrm{ha}^{-1}$ of $\mathrm{P}$, plant height and stem diameter increased by about $8.46 \%$ and $5.53 \%$, respectively, when compared to the treatment inoculated and fertilized with $160 \mathrm{~kg} \mathrm{ha}^{-1}$ of P. Conversely, in the treatment co-inoculated and without phosphate fertilization, these increments were approximately $72.59 \%$ for plant height and $30.15 \%$ for stem diameter, respectively. The positive effect of co-inoculation with Bradyrhizobium sp. + Azospirillum brasilense on the growth of cowpea plants was observed only at higher $\mathrm{P}$ doses in the soil. 
Table 3. Plant height, stem diameter, number of leaves, number of nodules, number of pods per plant, number of grains per pod and number of grains per plant in different cowpea genotypes inoculated and co-inoculated with rhizobacteria in association with phosphate fertilization. Colorado do Oeste, RO, Brazil (2018)

\begin{tabular}{|c|c|c|c|c|c|c|c|c|}
\hline \multirow{4}{*}{ Bacteria } & \multicolumn{8}{|c|}{ Doses de $\mathrm{P}_{2} \mathrm{O}_{5}\left(\mathrm{~kg} \mathrm{ha}^{-1}\right)$} \\
\hline & \multicolumn{2}{|c|}{0} & \multicolumn{2}{|c|}{80} & \multicolumn{2}{|c|}{120} & \multicolumn{2}{|c|}{160} \\
\hline & \multicolumn{2}{|c|}{ Genotype } & \multicolumn{2}{|c|}{ Genotype } & \multicolumn{2}{|c|}{ Genotype } & \multicolumn{2}{|c|}{ Genotype } \\
\hline & White & Butter & White & Butter & White & Butter & White & Butter \\
\hline \multicolumn{9}{|c|}{ Plant height $(\mathrm{cm})$} \\
\hline NI & $50.00 \mathrm{aDb}$ & $31.00 \mathrm{bCa}$ & $78.00 \mathrm{aCc}$ & $65.66 \mathrm{bBc}$ & $93,00 \mathrm{aBb}$ & $89,66 \mathrm{aAb}$ & $108,00 \mathrm{aAc}$ & $60,16 \mathrm{bBc}$ \\
\hline I & $76.33 \mathrm{aDa}$ & $44.00 \mathrm{bCb}$ & $94.33 \mathrm{aCb}$ & $74.36 \mathrm{bBb}$ & $113,67 \mathrm{aBa}$ & $95,00 \mathrm{bAa}$ & $122,00 \mathrm{aAb}$ & $75,00 \mathrm{bBb}$ \\
\hline $\mathrm{CO}$ & $76.67 \mathrm{aCa}$ & $62.33 \mathrm{bCa}$ & $113.00 \mathrm{aBa}$ & $87.33 \mathrm{bBa}$ & $113,00 \mathrm{aBa}$ & $96,67 \mathrm{bAa}$ & 132,33 aAa & $93,33 \mathrm{bBa}$ \\
\hline \multicolumn{9}{|c|}{ Stem diameter $(\mathrm{mm})$} \\
\hline NI & $11.48 \mathrm{aCb}$ & $6.65 \mathrm{bCb}$ & $13.58 \mathrm{aBa}$ & $10.22 \mathrm{bAa}$ & $13.38 \mathrm{aBb}$ & $10.98 \mathrm{bAa}$ & $14.82 \mathrm{aAc}$ & $8.30 \mathrm{bBb}$ \\
\hline I & $12.99 \mathrm{aCa}$ & $7.05 \mathrm{bCb}$ & $14.65 \mathrm{aCa}$ & $11.53 \mathrm{bAa}$ & $15.25 \mathrm{aAa}$ & $11.80 \mathrm{bAa}$ & $15.85 \mathrm{aAb}$ & $8.97 \mathrm{bBb}$ \\
\hline $\mathrm{CO}$ & $12.90 \mathrm{aBa}$ & $9.61 \mathrm{bCa}$ & $13.42 \mathrm{aBa}$ & $11.09 \mathrm{bAa}$ & $14.31 \mathrm{aBa}$ & $12.30 \mathrm{bAa}$ & $16.79 \mathrm{aAa}$ & $11.44 \mathrm{bAa}$ \\
\hline \multicolumn{9}{|c|}{ Number of leaves (un.) } \\
\hline NI & $10.66 \mathrm{aCb}$ & $10.00 \mathrm{aCc}$ & $20.33 \mathrm{bBb}$ & $22.66 \mathrm{aBc}$ & $25.33 \mathrm{bAb}$ & $30.66 \mathrm{aAc}$ & $22.00 \mathrm{bAb}$ & $33.00 \mathrm{aAc}$ \\
\hline I & $15.00 \mathrm{aDa}$ & $22.00 \mathrm{aCa}$ & $23.33 \mathrm{bCa}$ & $27.00 \mathrm{aBb}$ & $27.00 \mathrm{bBb}$ & $50.33 \mathrm{aAa}$ & $31.00 \mathrm{bAa}$ & $50.00 \mathrm{aAb}$ \\
\hline $\mathrm{CO}$ & $16.00 \mathrm{aDa}$ & $24.33 \mathrm{aCa}$ & $20.66 \mathrm{bCb}$ & $50.33 \mathrm{aBa}$ & $32.66 \mathrm{bBa}$ & $54.66 \mathrm{aAa}$ & $37.66 \mathrm{bAa}$ & $55.33 \mathrm{aAa}$ \\
\hline \multicolumn{9}{|c|}{ Number of nodules (un.) } \\
\hline NI & $10.00 \mathrm{bCb}$ & $6.00 \mathrm{bDb}$ & $52.66 \mathrm{bBc}$ & $171.00 \mathrm{aBb}$ & $83.00 \mathrm{bAc}$ & $227.00 \mathrm{aAb}$ & $48.00 \mathrm{bBb}$ & $109.33 \mathrm{aCb}$ \\
\hline I & $33.33 \mathrm{aDa}$ & $32.00 \mathrm{aDa}$ & $96.00 \mathrm{bCb}$ & $17500 \mathrm{aBb}$ & $111.00 \mathrm{bAb}$ & $274.00 \mathrm{aAa}$ & $94.33 \mathrm{bBa}$ & $168.00 \mathrm{aCa}$ \\
\hline $\mathrm{CO}$ & $31.00 \mathrm{aDa}$ & $40.66 \mathrm{aDa}$ & $133.33 \mathrm{bBa}$ & $190.00 \mathrm{aBa}$ & $180.00 \mathrm{bAa}$ & $218.00 \mathrm{aAa}$ & $82.00 \mathrm{bCa}$ & $164.66 \mathrm{aCa}$ \\
\hline \multicolumn{9}{|c|}{ Number of pods per plant (un.) } \\
\hline NI & $0.00 \mathrm{aCb}$ & $0.00 \mathrm{aDb}$ & $8.00 \mathrm{bBb}$ & $16.00 \mathrm{aCb}$ & $11.33 \mathrm{bAb}$ & $22.33 \mathrm{aAb}$ & $12.00 \mathrm{bAb}$ & $20.00 \mathrm{aBb}$ \\
\hline I & $10.00 \mathrm{bBa}$ & $16.00 \mathrm{aCa}$ & $11.66 \mathrm{bAa}$ & $20.00 \mathrm{aBa}$ & $12.66 \mathrm{bAa}$ & $25.00 \mathrm{aAa}$ & $10.33 \mathrm{bBa}$ & $21.00 \mathrm{aBb}$ \\
\hline $\mathrm{CO}$ & $11.00 \mathrm{bBa}$ & $18.00 \mathrm{aDa}$ & $11.00 \mathrm{bBa}$ & $20.00 \mathrm{aCa}$ & $13.00 \mathrm{bAa}$ & $25.00 \mathrm{aAa}$ & $12.33 \mathrm{bAa}$ & $23.00 \mathrm{aBa}$ \\
\hline \multicolumn{9}{|c|}{ Number of grains per pod (un.) } \\
\hline NI & $0.00 \mathrm{aBb}$ & $0.00 \mathrm{aBb}$ & $14.66 \mathrm{aAb}$ & $15.66 \mathrm{aAb}$ & $15.00 \mathrm{aAb}$ & $17.00 \mathrm{aAa}$ & $15.66 \mathrm{aAa}$ & $15.00 \mathrm{aAa}$ \\
\hline I & $15.66 \mathrm{aAa}$ & $16.66 \mathrm{aAa}$ & $16.33 \mathrm{aAa}$ & $17.00 \mathrm{aAa}$ & $17.00 \mathrm{aAa}$ & $16.33 \mathrm{aABa}$ & $16.00 \mathrm{aAa}$ & $16.00 \mathrm{aAa}$ \\
\hline $\mathrm{CO}$ & $15.33 \mathrm{aBa}$ & $15.00 \mathrm{aABa}$ & $17.89 \mathrm{aAa}$ & $18.00 \mathrm{aAa}$ & $16.00 \mathrm{aBa}$ & $16.66 \mathrm{aAa}$ & $15.66 \mathrm{aBa}$ & $16.00 \mathrm{aAa}$ \\
\hline \multicolumn{9}{|c|}{ Number of grains per plant (un.) } \\
\hline NI & $0.00 \mathrm{aCb}$ & $0.00 \mathrm{aDb}$ & $117.33 \mathrm{bBb}$ & $250.00 \mathrm{aCb}$ & $169.66 \mathrm{bAa}$ & $379.66 \mathrm{aAb}$ & $188.33 \mathrm{bAb}$ & $310.00 \mathrm{aBb}$ \\
\hline I & $161.00 \mathrm{bCa}$ & $210.00 \mathrm{aCa}$ & $190.33 \mathrm{bABa}$ & $340.00 \mathrm{aBa}$ & $215.33 \mathrm{bAa}$ & $408.00 \mathrm{aAa}$ & $165.33 \mathrm{bCa}$ & $325.00 \mathrm{aBa}$ \\
\hline $\mathrm{CO}$ & $173.33 \mathrm{bCa}$ & $275.00 \mathrm{aDa}$ & $196.66 \mathrm{bBa}$ & $340.00 \mathrm{aCa}$ & $208.33 \mathrm{bAa}$ & $416.66 \mathrm{aAa}$ & $193.66 \mathrm{bBa}$ & $368.00 \mathrm{aBa}$ \\
\hline
\end{tabular}

Note. Lowercase letters separate means in each column for the factor genotype, uppercase letters separate means in the row for the factor phosphorus doses, and lowercase letters separate means in the row for the factor bacterium. Equal letters do not differ by Tukey test at 0.05 probability level. NI: no inoculation; I: inoculation with Bradyrhizobium sp.; CO: inoculation with Bradyrhizobium sp + Azospirillum brasilense.

Opposite results were found for the number of leaves, number of nodules, number of pods per plant and number of grains per plant. Simple-effect analysis of the triple interaction revealed that the genotype Butter was statistically $(\mathrm{p} \leq 0.05)$ superior to the genotype White when inoculated and fertilized with $120 \mathrm{~kg} \mathrm{ha}^{-1}$ of $\mathrm{P}$, not differing statistically from the treatment co-inoculated and fertilized with $120 \mathrm{~kg} \mathrm{ha}^{-1}$ of P (Table 3). The dose of $120 \mathrm{~kg} \mathrm{ha}^{-1}$ of $\mathrm{P}$ in the presence of Bradyrhizobium sp. led to increments of $64.15 \%, 20.70 \%, 11.95 \%$ and $7.46 \%$, respectively, in the number of leaves, nodules, pods and grains of cowpea, when compared with the treatment fertilized with $120 \mathrm{~kg} \mathrm{ha}^{-1}$ of $\mathrm{P}$ and without inoculation. When the treatment inoculated and fertilized with 120 $\mathrm{kg} \mathrm{ha}^{-1}$ of P was compared with the treatment inoculated with Bradyrhizobium sp. and without phosphate fertilization, such increment exceeds $100 \%$ for the number of leaves and number of nodules, $56.25 \%$ for the number of pods and $94.28 \%$ for the number of grains per plant. These data revealed positive effect of inoculation with Bradyrhizobium sp. when associated with phosphate fertilization. It is possible to note an aid in symbiosis because, when the nutrient is applied, there is greater formation of nodules in the roots, since $\mathrm{P}$ is source of 
energy to the plant, which, when well nourished, provides carbohydrates to rhizobacteria, helping the development of nodules (Figure 2), up to a certain limit of fertilization, which allows the inference that symbiosis can be limited under very low and/or very high levels of phosphorus, as shown by the data (Table 3 ). In the control treatment (without inoculation and without fertilization), there was low formation of nodules in both genotypes studied, which confirms that there was low contamination and low population of nodulating bacteria established in the soil. The development of nodules, even under limited quantity of nutrient in the soil, is most likely associated with the capacity of the rhizobium to solubilize non-labile phosphate of the soil and release it to the plant. For cowpea, there is no conclusive information on the minimum number of nodules necessary to guarantee good performance in BNF. However, in the present study, both genotypes had enough capacity to form nodules to guarantee BNF when inoculated and fertilized with $\mathrm{P}$.

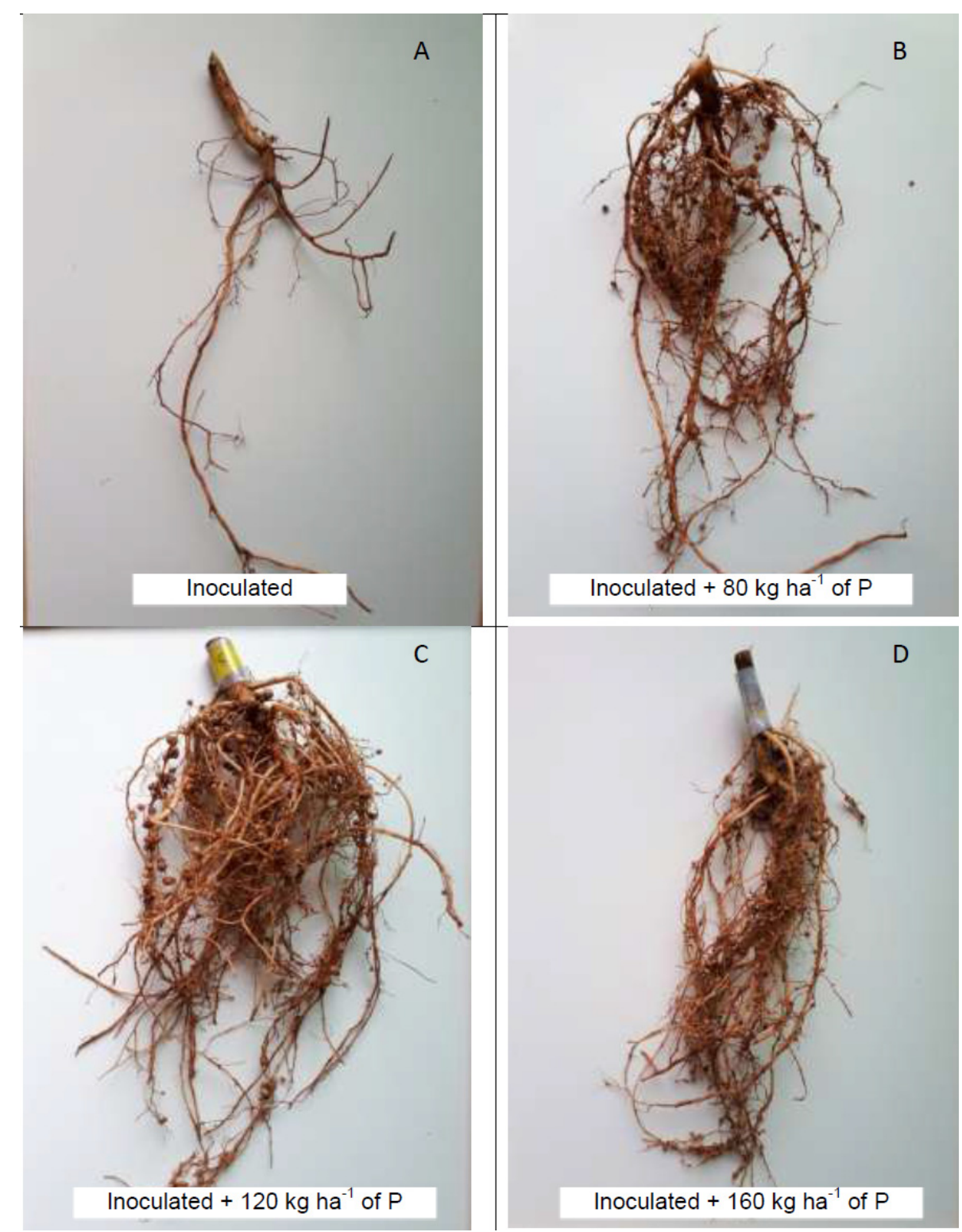

Figure 2. Roots of the genotype Manteiga inoculated with Bradyrhizobium sp. (Semia 6462 and Semia 6463) and fertilized with different rates of P. (A) Inoculated; (B) Inoculated $+80 \mathrm{~kg} \mathrm{ha}^{-1}$; inoculated $+120 \mathrm{~kg} \mathrm{ha}^{-1}(\mathrm{C})$ and (D) Inoculated $+160 \mathrm{~kg} \mathrm{ha}^{-1}$

Regarding the number of grains per pod, there was no significant difference $(\mathrm{p} \leq 0.05)$ between the cowpea genotypes at the different doses of $\mathrm{P}$, whereas the for factor bacterium there was statistical difference from the 
control (without inoculation and without fertilization). Between the treatments inoculated and co-inoculated for both genotypes, there was also no significant difference $(p \leq 0.05)$ for the production of grains per pod. It can be observed that only the inoculation with Bradyrhizobium sp. is sufficient to promote higher number of grains per pod, with no need for association with either phosphate fertilization or co-inoculation with rhizobacteria (Table 3), which becomes an option for family farming and/or subsistence farming considering the costs of phosphate fertilizers.

For the production of shoot, root and total dry matter, the genotype White as statistically superior $(p \leq 0.05)$ to the genotype Butter when inoculated and fertilized with $120 \mathrm{~kg} \mathrm{ha}^{-1}$ of $\mathrm{P}$, not differing statistically from the treatment co-inoculated and fertilized with $120 \mathrm{~kg} \mathrm{ha}^{-1}$ of $\mathrm{P}$. The rate of $120 \mathrm{~kg} \mathrm{ha}^{-1}$ of $\mathrm{P}$, in the presence of Bradyrhizobium sp., led to increments of $38.07 \%, 58.52 \%$ and $49.34 \%$, respectively, in shoot, root and total dry matter, compared with the treatment inoculated with Bradyrhizobium sp. and without phosphate fertilization (Table 4), confirming the synergism between phosphate fertilization and inoculation with rhizobacteria in cowpea plants. This can be also explained because P helps increase the growth of root hairs, which are sites of infection for bacteria. Thus, in environment with low availability of $\mathrm{P}$, bacterium efficiency is limited by the lack of infection sites, a problem that is solved when adequate rates of $\mathrm{P}$ are applied. When the production of shoot, root and total dry matter in the treatment inoculated with Bradyrhizobium sp. and fertilized with $120 \mathrm{~kg} \mathrm{ha}^{-1}$ of $\mathrm{P}$ is compared with the values in the control treatment (without inoculation and without fertilization), the increments are $89.30 \%, 268 \%$ and $177 \%$, respectively.

Table 4. Shoot dry matter, root dry matter and total dry matter of different cowpea genotypes inoculated and co-inoculated with rhizobacteria in association with phosphate fertilization. Colorado do Oeste, RO, Brazil (2018)

\begin{tabular}{|c|c|c|c|c|c|c|c|c|}
\hline \multirow{4}{*}{ Bacteria } & \multicolumn{8}{|c|}{ Doses de $\mathrm{P}_{2} \mathrm{O}_{5}\left(\mathrm{~kg} \mathrm{ha}^{-1}\right)$} \\
\hline & \multicolumn{2}{|c|}{0} & \multicolumn{2}{|c|}{80} & \multicolumn{2}{|c|}{120} & \multicolumn{2}{|c|}{160} \\
\hline & \multicolumn{2}{|c|}{ Genotype } & \multicolumn{2}{|c|}{ Genotype } & \multicolumn{2}{|c|}{ Genotype } & \multicolumn{2}{|c|}{ Genotype } \\
\hline & White & Butter & White & Butter & White & Butter & White & Butter \\
\hline \multicolumn{9}{|c|}{ Shoot dry matter (g) } \\
\hline NI & $50.33 \mathrm{aCb}$ & $34.00 \mathrm{bCb}$ & $70.31 \mathrm{aBb}$ & $57.66 \mathrm{bBb}$ & $87.74 \mathrm{aAb}$ & $64.00 \mathrm{bAb}$ & $64.21 \mathrm{aCa}$ & $65.66 \mathrm{aAb}$ \\
\hline I & $72.97 \mathrm{aCa}$ & $35.66 \mathrm{bCa}$ & $90.08 \mathrm{aBa}$ & $74.66 \mathrm{bBa}$ & $100.75 \mathrm{aAa}$ & $93.33 \mathrm{bAa}$ & $71.77 \mathrm{aCa}$ & $83.33 \mathrm{aAa}$ \\
\hline $\mathrm{CO}$ & $73.24 \mathrm{aCa}$ & $40.33 \mathrm{bCa}$ & $86.70 \mathrm{aBa}$ & $75.66 \mathrm{bBa}$ & $100.75 \mathrm{aAa}$ & $84.66 \mathrm{bAa}$ & $78.49 \mathrm{aCa}$ & $86.66 \mathrm{aAa}$ \\
\hline \multicolumn{9}{|c|}{ Root dry matter (g) } \\
\hline NI & $5.89 \mathrm{aCb}$ & $4.00 \mathrm{bCb}$ & $13.66 \mathrm{aBb}$ & $10.00 \mathrm{bBb}$ & $18.33 \mathrm{bAb}$ & $20.00 \mathrm{aAb}$ & $18.00 \mathrm{aAb}$ & $11.66 \mathrm{bBc}$ \\
\hline I & $9.00 \mathrm{aCa}$ & $6.00 \mathrm{bDa}$ & $19.26 \mathrm{aBa}$ & $12.66 \mathrm{bCa}$ & $21.70 \mathrm{bAa}$ & $24.66 \mathrm{aAa}$ & $19.82 \mathrm{bBa}$ & $22.33 \mathrm{aBa}$ \\
\hline $\mathrm{CO}$ & $8.70 \mathrm{aCa}$ & $6.00 \mathrm{bDa}$ & $20.50 \mathrm{aBa}$ & $13.66 \mathrm{bCa}$ & $22.30 \mathrm{bAa}$ & $26.33 \mathrm{aAa}$ & $20.12 \mathrm{aBa}$ & $15.33 \mathrm{bBb}$ \\
\hline \multicolumn{9}{|c|}{ Total dry matter $(g)$} \\
\hline NI & $56.23 \mathrm{aCb}$ & $38.00 \mathrm{bCb}$ & $84.00 \mathrm{aBb}$ & $67.66 \mathrm{bBb}$ & $106.07 \mathrm{aAb}$ & $84.00 \mathrm{bAb}$ & $82.21 \mathrm{aBb}$ & $77.33 \mathrm{aBb}$ \\
\hline I & $81.99 \mathrm{aCa}$ & $41.66 \mathrm{bCa}$ & $109.34 \mathrm{aBa}$ & $87.33 \mathrm{bBa}$ & $122.45 \mathrm{aAa}$ & $118.00 \mathrm{bAa}$ & $91.59 \mathrm{aCa}$ & $105.66 \mathrm{bAa}$ \\
\hline $\mathrm{CO}$ & $81.94 \mathrm{aCa}$ & $46.33 \mathrm{bCa}$ & $107.20 \mathrm{aBa}$ & $89.33 \mathrm{aBa}$ & $123.05 \mathrm{aAa}$ & $111.00 \mathrm{bAa}$ & $98.61 \mathrm{aCa}$ & $102.00 \mathrm{aAa}$ \\
\hline
\end{tabular}

Note. Lowercase letters separate means in each column for the factor genotype, uppercase letters separate means in the row for the factor phosphorus doses, and lowercase letters separate means in the row for the factor bacterium. Equal letters do not differ by Tukey test at 0.05 probability level. NI: no inoculation; I: inoculation with Bradyrhizobium sp.; CO: inoculation with Bradyrhizobium sp + Azospirillum brasilense.

Maximum grain yield was obtained by the genotype White in the treatment inoculated with Bradyrhizobium sp. and fertilized with $120 \mathrm{~kg} \mathrm{ha}^{-1}$ of $\mathrm{P}$, which did not differ statistically $(\mathrm{p} \leq 0.05)$ from the treatment co-inoculated and fertilized with $120 \mathrm{~kg} \mathrm{ha}^{-1}$ of P (Table 5). The yield of the genotype Branco inoculated and fertilized with $120 \mathrm{~kg} \mathrm{ha}^{-1}$ of $\mathrm{P}$ was $916.85 \mathrm{~kg} \mathrm{ha}^{-1}$, whereas the yield in the treatment only inoculated with Bradyrhizobium sp. was $763.42 \mathrm{~kg} \mathrm{ha}^{-1}$, which represents an increase of about $20 \%$ in grain yield (Table 5). It was possible to observe that at higher $\mathrm{P}$ doses the association with rhizobacteria was hampered, because grain yield decreased in both cowpea genotypes evaluated. However, inoculation with Bradyrhizobium sp. associated with phosphate fertilization of $120 \mathrm{~kg} \mathrm{ha}^{-1}$ of $\mathrm{P}$ was sufficient to promote maximum growth and development of cowpea plants. 
It is necessary to consider also that the genetic potential of the plant, as well as its adaptability to field conditions, influences grain yield (Mello et al., 2009).

Table 5. Yield of different cowpea genotypes inoculated and co-inoculated with rhizobacteria in association with phosphate fertilization. Colorado do Oeste, RO, Brazil (2018)

\begin{tabular}{|c|c|c|c|c|c|c|c|c|}
\hline \multirow{4}{*}{ Bacteria } & \multicolumn{8}{|c|}{ Doses de $\mathrm{P}_{2} \mathrm{O}_{5}\left(\mathrm{~kg} \mathrm{ha}^{-1}\right)$} \\
\hline & \multicolumn{2}{|c|}{0} & \multicolumn{2}{|c|}{80} & \multicolumn{2}{|c|}{120} & \multicolumn{2}{|c|}{160} \\
\hline & \multicolumn{2}{|c|}{ Genotype } & \multicolumn{2}{|c|}{ Genotype } & \multicolumn{2}{|c|}{ Genotype } & \multicolumn{2}{|c|}{ Genotype } \\
\hline & White & Butter & White & Butter & White & Butter & White & Butter \\
\hline \multicolumn{9}{|c|}{ Yield $\left(\mathrm{kg} \mathrm{ha}^{-1}\right)$} \\
\hline $\mathrm{NI}$ & $0.00 \mathrm{aCb}$ & $0.00 \mathrm{aCb}$ & $554.07 \mathrm{aBb}$ & $382.96 \mathrm{bBb}$ & $801.20 \mathrm{aAb}$ & 580.04 bAa & $889.35 \mathrm{aAa}$ & $488.88 \mathrm{bAa}$ \\
\hline I & $763.42 \mathrm{aCa}$ & $321.85 \mathrm{bCa}$ & $898.79 \mathrm{aBa}$ & $519.44 \mathrm{bAa}$ & $916.85 \mathrm{aAa}$ & $623.33 \mathrm{bAa}$ & $780.74 \mathrm{aCb}$ & $481.25 \mathrm{bBa}$ \\
\hline $\mathrm{CO}$ & $818.51 \mathrm{aCa}$ & $420.13 \mathrm{bCa}$ & $928.70 \mathrm{aBa}$ & $519.44 \mathrm{bBa}$ & $983.79 \mathrm{aAa}$ & $636.57 \mathrm{bAa}$ & $914.53 \mathrm{aBa}$ & $562.22 \mathrm{bAa}$ \\
\hline
\end{tabular}

Note. Lowercase letters separate means in each column for the factor genotype, uppercase letters separate means in the row for the factor phosphorus doses, and lowercase letters separate means in the row for the factor bacterium. Equal letters do not differ by Tukey test at 0.05 probability level. NI: no inoculation; I: inoculation with Bradyrhizobium sp.; CO: inoculation with Bradyrhizobium sp + Azospirillum brasilense.

Inoculation of Bradyrhizobium sp. led to higher $\mathrm{N}$ and $\mathrm{P}$ contents in the leaves of cowpea at full flowering, not differing statistically $(\mathrm{p} \leq 0.05)$ from the co-inoculated treatment (Bradyrhizobium $\mathrm{sp} .+$ Azospirillum brasilense) The mean contents of $\mathrm{N}$ and $\mathrm{P}$ in the leaves of cowpea inoculated and co-inoculated with rhizobacteria were $35.51 \mathrm{~g} \mathrm{~kg}^{-1}$ and $2.58 \mathrm{~g} \mathrm{~kg}^{-1}$, showing increments in comparison to the control treatment (without inoculation and without fertilization) of about $6.49 \%$ and $10.94 \%$, respectively (Figures 3A and 3C). It has been confirmed that the population of rhizobia inoculated and indicated for cowpea is able to perform symbiosis and supply the $\mathrm{N}$ and $\mathrm{P}$ required for crop development, and that the inoculant was effective in the biological fixation process because it led to higher $\mathrm{N}$ fixation by the plant, compared with the control treatment. Corroborating these results, Araújo et al. (2018) and Araújo et al. (2017) found increments in $\mathrm{N}$ and P contents in the leaves of cowpea when inoculated with strains of Bradyrhizobium sp., not differing statistically from the co-inoculated treatment.

Cowpea is characterized by low requirement of $\mathrm{P}$ but has shown greater and frequent response when grown in soil with good availability of the nutrient (Araújo et al., 2018). The contents of N, P, K and Ca in cowpea leaves responded significantly $(\mathrm{p} \leq 0.05)$ to the increment in $\mathrm{P}$ doses, and their maximum contents in the leaves were $37.64 \mathrm{~g} \mathrm{~kg}^{-1}, 2.74 \mathrm{~g} \mathrm{~kg}^{-1}, 16.53 \mathrm{~g} \mathrm{~kg}^{-1}$ and $44.01 \mathrm{~g} \mathrm{~kg}^{-1}$, respectively, obtained at the dose of $120 \mathrm{~kg} \mathrm{ha}^{-1}$ (Figures $3 \mathrm{~B}, 3 \mathrm{D}, 3 \mathrm{~F}$ and $3 \mathrm{H}$ ), with a reduction at higher doses. Such increase in leaf contents of macronutrients with the application of phosphate fertilization can explain a future increase in grain production, considering that there are reports in the literature about the close correlation between leaf contents of nutrients and yield of crops (Araujo et al., 2017).

The genotype Butter was statistically superior $(\mathrm{p} \leq 0.05)$ to the genotype White for the accumulation of $\mathrm{P}, \mathrm{K}, \mathrm{Ca}$ and $\mathrm{Mg}$ in the leaves at full flowering (Figures 3C, 3E, 3G and 3I). This demonstrates that the genotype Butter is more efficient than White in absorbing these macronutrients under the study conditions, which can be attributed to the higher number of viable nodules. This can also be attributed to the existence of different nutritional behavior due to genetic factors of adaptability between the genotypes. Similar results were obtained by Araújo et al. (2018), evaluating the effects of inoculation and co-inoculation of rhizobacteria in association with phosphate fertilization on the absorption of macronutrients by different cowpea genotypes grown in southern Amazonas state. 

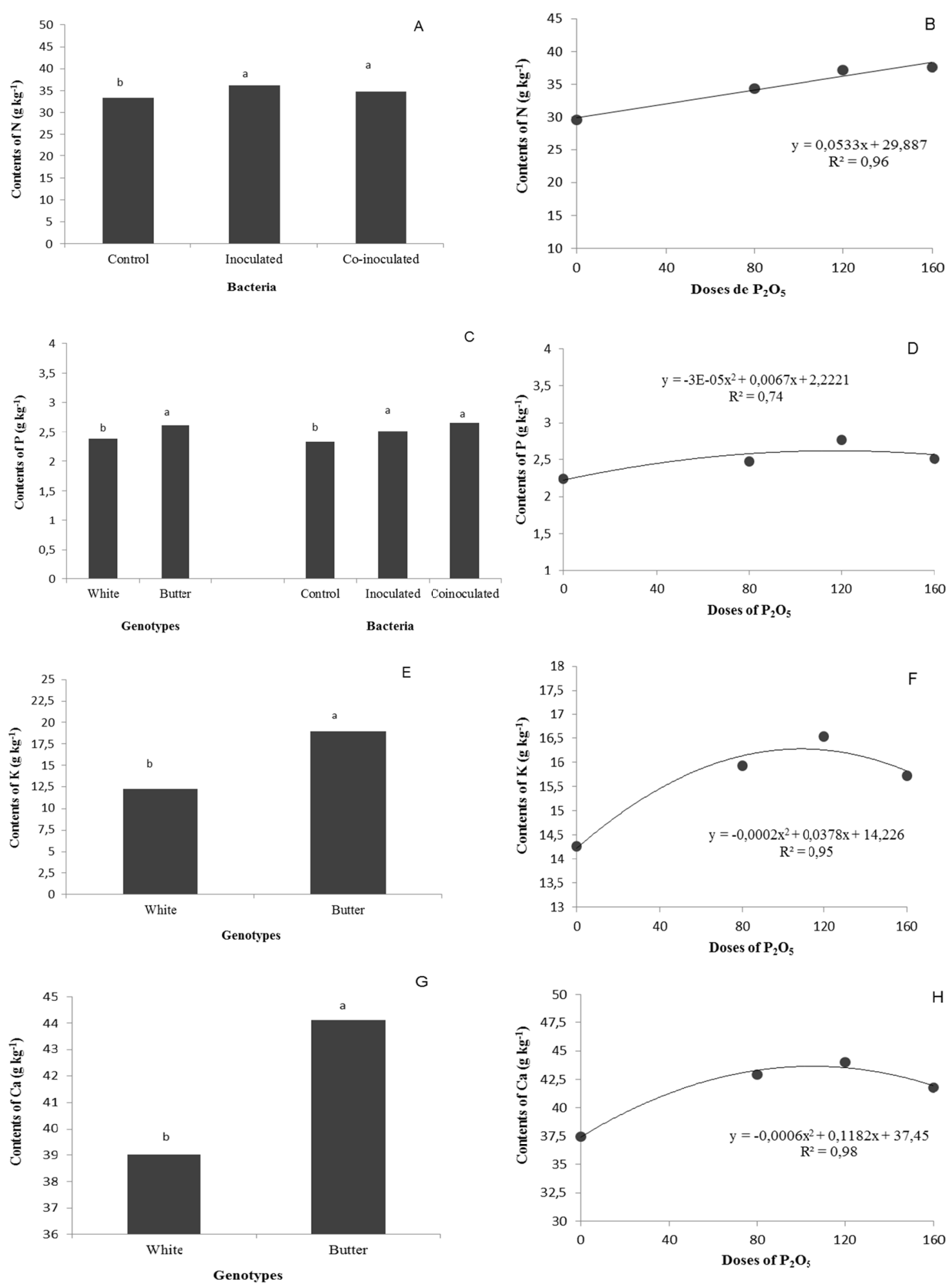

Figure 3. Contents of N, P, K, Ca, Mg and S in the leaves of different cowpea genotypes in response to inoculation and co-inoculation with rhizobacteria in association with phosphate fertilization. Medium followed by the same letter, do not differ statistically between themselves by Tukey a $5 \%$ probability

\section{Conclusions}

Co-inoculation (Bradyrhizobium sp. + Azospirillum brasilense) did not influence the production components of cowpea plants. 
Inoculation of Bradyrhizobium sp. associated with phosphate fertilization of $120 \mathrm{~kg} \mathrm{ha}^{-1}$ of $\mathrm{P}_{2} \mathrm{O}_{5}$ was sufficient to promote maximum growth and development of cowpea plants in Amazonian soil.

The genotype Branco showed higher capacity of nodulation, dry matter production and grain yield.

Inoculation of Bradyrhizobium sp. increased $\mathrm{N}$ and $\mathrm{P}$ contents in the leaves.

The genotype Butter was superior to the genotype White with respect to the accumulation of $\mathrm{P}, \mathrm{K}, \mathrm{Ca}$ and $\mathrm{Mg}$ in the leaves.

\section{Acknowlegements}

The authors thank the "Luiz de Queiroz" Foundation for Agrarian Research and the Federal Institute of Education, Science and Technology of Rondônia for the financial support, and the Federal University of Grande Dourados for the opportunity for the first author to take part in the post-doctoral training program.

\section{References}

Araujo, E. O., Mauad, M., Tadeu, H. C., Lima Filho, H. A., Silva, J. A. F., \& Cardoso, J. A. (2018). Nutritional status of cowpea plants inoculated with Bradyrhizobium and Azospirillum brasilense in associated with phosphate fertilization in soil Amazonian. Journal of Experimental Agriculture Internacional, 23(5), 1-13. https://doi.org/10.9734/JEAI/2018/42145

Araujo, E. O., Gerola, J. G., Ferreira, C. R. G., \& Matte, L. C. (2017). Effect of rates and sources of soluble phosphorus on the behavior of cowpea plants inoculated with rhizobacteria from soils of the north region of Brazil. African Journal Microbiology Research, 11(42), 1544-1550. https://doi.org/10.5897/AJMR2017. 8649

Araujo, E. O., Santos, E. F., \& Camacho, M. A. (2012). Nutritional efficiency of cowpea varieties in the absorption of phosphorus. Agronomía Colombiana, 30(3), 419-424.

Burity, H. A., Lyra, M. C. C. P., \& Souza, E. S. (2000). Effectiveness of inoculation with rhizobium and arbuscular mycorrhizal fung in thrush seedlings subjected to different levels of phosphorus. Agricultural Research Brazilian, 35, 801-807.

CONAB. (2018). Monitoring the Brazilian grain harvest 2017/2018: Fifth survey, February/2018, national supply company (p. 140). Brasília, CONAB.

Coutinho, W. R., Da silva, D. M. S., Saldenha, E. C. M., Okumura, R. S., \& Silva junior, M. L. (2014). Rates of phosphorus in the cowpea crop in the northeastern region of the State of Pará.Agro@mbiente Magazine Online, 8(1), 66-73. https://doi.org/10.18227/1982-8470ragro.v8i1.1310

EMBRAPA (Empresa Brazilian of Agricultural Research). (2009). Manual of chemical analysis of soils, plants and fertilizers (2nd ed., p. 627). Brasilia., Embrapa information technology.

Hara, F. A. dos S., \& Oliveira, L. A. de. (2007). Physiological and ecological characteristics of rhizobia isolated from acidic soil and álicos of Presidente Figueiredo, Amazon. Acta Amazonica, 34, 343-357.

Hungria, M., Campo, R. J., \& Mendes, I. C. (2007). The importance of the process of biological nitrogen fixation for soybean culture: component essential to the competitiveness of the Brazilian product (p. 80). London: Embrapa soy.

Melo, S. R., \& Zilli, J. E. (2009). Biological nitrogen fixation on Cowpea cultivars recommended for the State of Roraima. Brazilian Agricultural Research, 44(9), 1177-1183.

Rocha, W. S. (2016). Inoculation and doses of phosphorus in Cowpea in the South of the State of Tocantins (p. 56). Gurupi: UFT.

Silva, A. J., Uchôa, S. C. P., Alves, J. M. A., Lima, A. C. S., Santos, C. S. V., Oliveira, J. M. F., \& Melo, V. F. (2010a). Response of cowpea to the rates and application forms of phosphorus in Yellow Latosol of the State of Roraima. Acta Amazonica, 40(1), 31-36. https://doi.org/10.1590/S0044-59672010000100004

Silva, E. F., Araujo, A. S. F., Santos, V. B., Nunes, A. P. L., \& Carneiro, R. F. V. (2010b). Biological N² fixation on cowpea under different doses and sources of phosphorus soluble. Bioscience Journal, 26(3), 394-402.

Zilli, J. E., Marson, L. C., Marson, B. F., Rumjanek, N. G., \& Xavier, G. R. (2009). Contribution of rhizobium strains for the development and productivity of cowpea beans in Roraima. Acta Amazônica, 39(4), 749-758. https://doi.org/10.1590/S0044-59672009000400003 
Zilli, J. E., Neto, M. L. S., Junior, I. F., Perin, L., \& Melo, A. R. (2011). Response by cowpea Bradyrhizobium inoculation with strains recommended for soybeans. Journal Brazilian Science Soil, 35(1), 739-742.

\section{Copyrights}

Copyright for this article is retained by the author(s), with first publication rights granted to the journal.

This is an open-access article distributed under the terms and conditions of the Creative Commons Attribution license (http://creativecommons.org/licenses/by/4.0/). 